\title{
GREEN MARKETING MIX BERPENGARUH TERHADAP KEPUTUSAN PEMBELIAN PRODUK BIG TREE FARMS DI LOTUS FOOD SERVICES
}

\author{
Muhammad Husnan Zaky ${ }^{1}$ \\ Ni Made Purnami² \\ ${ }^{1,2}$ Fakultas Ekonomi dan Bisnis Universitas Udayana, Bali, Indonesia \\ Email: muhammadhusnanzakyworld@gmail.com
}

\begin{abstract}
ABSTRAK
Pendekatan bauran pemasaran hijau (green marketing mix) diyakini dapat meningkatkan integrasi dari isu lingkungan pada seluruh aspek dari aktivitas perusahaan. Penelitian ini bertujuan untuk mengetahui pengaruh variabel-variabel green marketing mix (green product, green price, green place dan green promotion) terhadap keputusan pembelian produk Big Tree Frams. Sampel penelitian ditentukan dengan metode purposive samplingsebanyak 125 orang konsumen. Pengumpulan data dilakukan dengan menyebar kuesioner kepada konsumen produk Big Tree Farms di Lotus Food Services Jimbaran, Badung. Teknik analisis data dalam penelitian ini menggunakan analisis regresi linier berganda. Simpulan dari hasil penelitian adalah,Green marketing mix (green product, green price, green place dan green promotion) berpengaruh positif dan signifikan secara parsial terhadap keputusan pembelian produkBig Tree Frams di Lotus Food ServicesJimbaran, Badung.

Kata kunci : Green Marketing Mix, Keputusan Pembelian.
\end{abstract}

\begin{abstract}
The green marketing mix approach is believed to be able to increase the integration of environmental issues in all aspects of company activities. This study aims to determine the effect of green marketing mix variables (green product, green price, green place and green promotion) on purchasing decisions for Big Tree Frams products. The research sample was determined by a purposive sampling method of 125 consumers. Data collection was carried out by distributing questionnaires to consumers of Big Tree Farms products at Lotus Food Services Jimbaran, Badung. The data analysis technique in this study used multiple linear regression analysis. The conclusions from the results of the study are, Green marketing mix (green product, green price, green place and green promotion) has a positive and partially significant effect on the purchasing decisions of Big Tree Frams products at Lotus Food Services Jimbaran, Badung.

Keyword : Green Marketing Mix,Buying Decision
\end{abstract}




\section{PENDAHULUAN}

Permasalahan lingkungan dan kesehatan yang secara langsung dan tidak langsung diakibatkan oleh aktivitas manusia, baik di bidang ilmu pengetahuan dan teknologi, pertanian, ekonomi dan bisnis, telah menjadi issue sentral di semua kalangan. Kepedulian dan kesadaran akan lingkungan dan kesehatan, telah merubah cara pandang dan pola hidup dari manusia dan para pelaku usaha. Hal ini ditunjukkan pada perubahan pola pendekatan bisnis yang mulai mengarahkan usaha dengan pendekatan aktivitas bisnis berbasis kelestarian lingkungan. Pemasaran yang berbasis pada kelestarian lingkungan "environmental marketing" merupakan perkembangan baru dalam bidang pemasaran, dan merupakan suatu peluang yang potensial dan strategis yang memiliki keuntungan ganda (Multiplier effect) baik pelaku bisnis maupun masyarakat sebagai pengguna (Hanifah,2016).

Pendekatan pemasaran hijau (green marketing approach) pada area produk diyakini dapat meningkatkan integrasi dari isu lingkungan pada seluruh aspek dari aktivitas perusahaan, mulai dari formulasi strategi, perencanaan, penyusunan, sampai produksi dan penyaluran atau distribusi dengan pelanggan (Manongko, 2011). Green marketingtelah lama muncul yaitu sekitar akhir tahun 1980. Lompatan baru dunia marketing dengan buku John Grant yang berjudul "The Green marketing Manifesto" membuat kepekaan dunia usaha semakin tinggi terhadap lingkungan hidup (Hariyani, 2013). Perubahan ini menimbulkan tantangan yang harus dijawab bagi perusahaan, bisa berupa peluang atau ancaman. Perusahaan yang pintar akan memandang isu lingkungan hidup sebagai peluang untuk memuaskan kebutuhan dan keinginan konsumen, bukan ancaman. Perusahaan akan mengaplikasikan isu lingkungan dalam aktivitas pemasaran yang mereka lakukan, sehingga menimbulkan fenomena baru dalam dunia pemasaran berupa konsep green marketing.

Konsep pemasaran yang berorientasi terhadap masyarakat tidak hanya bertumpu pada pemenuhan kebutuhan masyarakat, tetapi juga dapat mensejahterakan melalui tanggung jawab terhadap lingkungan hidup sekitar. Perusahaan yang pintar akan memandang isu lingkungan sebagai peluang untuk mempengaruhi keputusan konsumen membeli produk. Perusahaan akan mengaplikasikan isu lingkungan dalam aktivitas pemasaran yang mereka lakukan, sehingga menimbulkan fenomena baru dalam dunia pemasaran berupa konsep pemasaran hijau (green marketing). Green marketing memanipulasi empat elemen dari bauran pemasaran (marketing mix) dalam 4P yaitu: product, price, place dan promotion untuk menjual produk dan jasa yang ditawarkan dengan menggunakan keunggulan pemeliharaan lingkungan hidup yang dibentuk dari pengelolaan limbah, efisiensi energi, dan penekanan pelepasan emisi beracun (Putripeni, 2014). Perbedaan bauran pemasaran hijau (green marketing mix) dengan bauran pemasaran (green marketing) konvensional terletak pada pendekatan lingkungan. Bauran pemasaran hijau mempertimbangkan aspek lingkungan, sedangkan bauran pemasaran (marketing mix) konvensional tanpa memperhatikan aspek lingkungan.

Pertanyaan yang muncul apakah pelaksanaan green marketing mix mampu mempengaruhi keputusan pembelian produk merujuk pada kepuasan kebutuhan, 
keinginan dan hasrat pelanggan dalam hubungan dengan pemeliharaan dan pelestarian dari lingkungan hidup? Hal ini didasarkan kepada produk yang bersertifikasi dengan adanya eco-label yang memberikan jaminan kepada konsumen bahwa produk yang dikonsumsi tersebut sudah melalui proses yang memperhatikan kaidah-kaidah pengelolaan lingkungan, selain menetapkan harga produk dengan harga premium sehingga harganya lebih mahal dibandingkan dengan harga produk sejenis yang tidak menerapkan green marketing mix.

Pendekatan bauran pemasaran hijau (green marketing mix) diyakini dapat meningkatkan integrasi dari isu lingkungan pada seluruh aspek dari aktivitas perusahaan, mulai dari formulasi strategi, perencanaan, penyusunan, sampai produksi dan penyaluran atau distribusi dengan pelanggan sehingga mempengaruhi keputusan pembelian (Dahlstrom, 2011:6). Pernyataan ini dipertegas beberapa hasil penelitian sebelumnya. Agustin (2015) dalam penelitiannya menemukan bahwa variabel green marketing dengan pendekatan marketing mix, yaitu produk ramah lingkungan, harga premium, distribusi ramah lingkungan dan promosi ramah lingkungan memiliki pengaruh terhadap keputusan pembelian. Hasil penelitian Syahbandi (2013) menemukan bahwa produk, harga, tempat dan promosi mempunyai pengaruh yang nyata positif terhadap pilihan konsumen. Konsumen sebagai pelanggan pada produk The Body Shop pada umumnya memiliki pengetahuan mengenai lingkungan yang baik dan memiliki sikap dan perilaku terkait lingkungan yang positif. Kampani (2014) membuktikan secara empiris bahwa green marketing mix berpengaruh langsung dan signifikan terhadap keputusan pembelian. Hasil penelitian ini menunjukkan nilai dan gaya hidup dalam diri konsumen menjadi faktor penting yang harus diperhatikan oleh praktisi pemasaran dalam hal ini pemasar produk ramah lingkungan.

PT Bening Big Tree Farms di Denpasar adalah perusahaan yang bergerak di bidang produksi bahan makanan organik yang ramah lingkungan dengan merek Big Tree Farms. Makanan organik berarti semua jenis produk yang berasal dari pertanian yang bebas dari pupuk buatan, bahan kimia atau bahan tambahan mulai dari awal pemrosesan, dimana semua bahan berasal dari alam. Berdasarkan hasil observasi, ditemukan beberapa permasalahan berkaitan dengan pelaksanaan green marketing mix produk Big Tree Farms di Lotus Food ServicesJimbaran, Badung. Produk dengan kemasan yang kurang baik atau cacat, seperti kemasan dengan kertas daur ulang yang robek dan kemasan dengan aluminium foilyang lepas. Potongan harga diberikan untuk beberapa jenis produk tertentu, itupun harus dengan pembelian dalam jumlah besar sehingga kurang menarik bagi konsumen untuk membeli produk dalam skala besar. Area parkir yang kurang luas, terutama pada saat kunjungan ramai mengganggu kenyamanan konsumen berbelanja. Kegiatan environmental advertisment melalui community marketing masih kurang dalam menggandeng komunitas dan organisasi non profit sehingga belum potensial untuk menyuarakan produk Big Tree Farms di Lotus Food ServicesJimbaran, Badung sebagai produk yang ramah lingkungan.

Hasil penelitian pra survey menunjukkan penilaian responden pada variabel Green product, green price, green place dan green promotion adalah tergolong baik, namun demikian terdapat gap antara penilaian responden yang ditunjukkan masih banyak indikator-indikator yang dipersepsikan konsumen masih belum baik 
dengan kategori cukup baik.Tercapainya tujuan pemasaran melalui pemenuhan kebutuhan dan keinginan konsumen harus didukung oleh pemahaman perilaku konsumen dalam sasaran pasar itu sendiri. Penting bagi PT Bening Big Tree Farms untuk mengetahui pengaruh green marketing mixterhadap keputusan pembelian produkdi Lotus Food ServicesJimbaran, Badung.

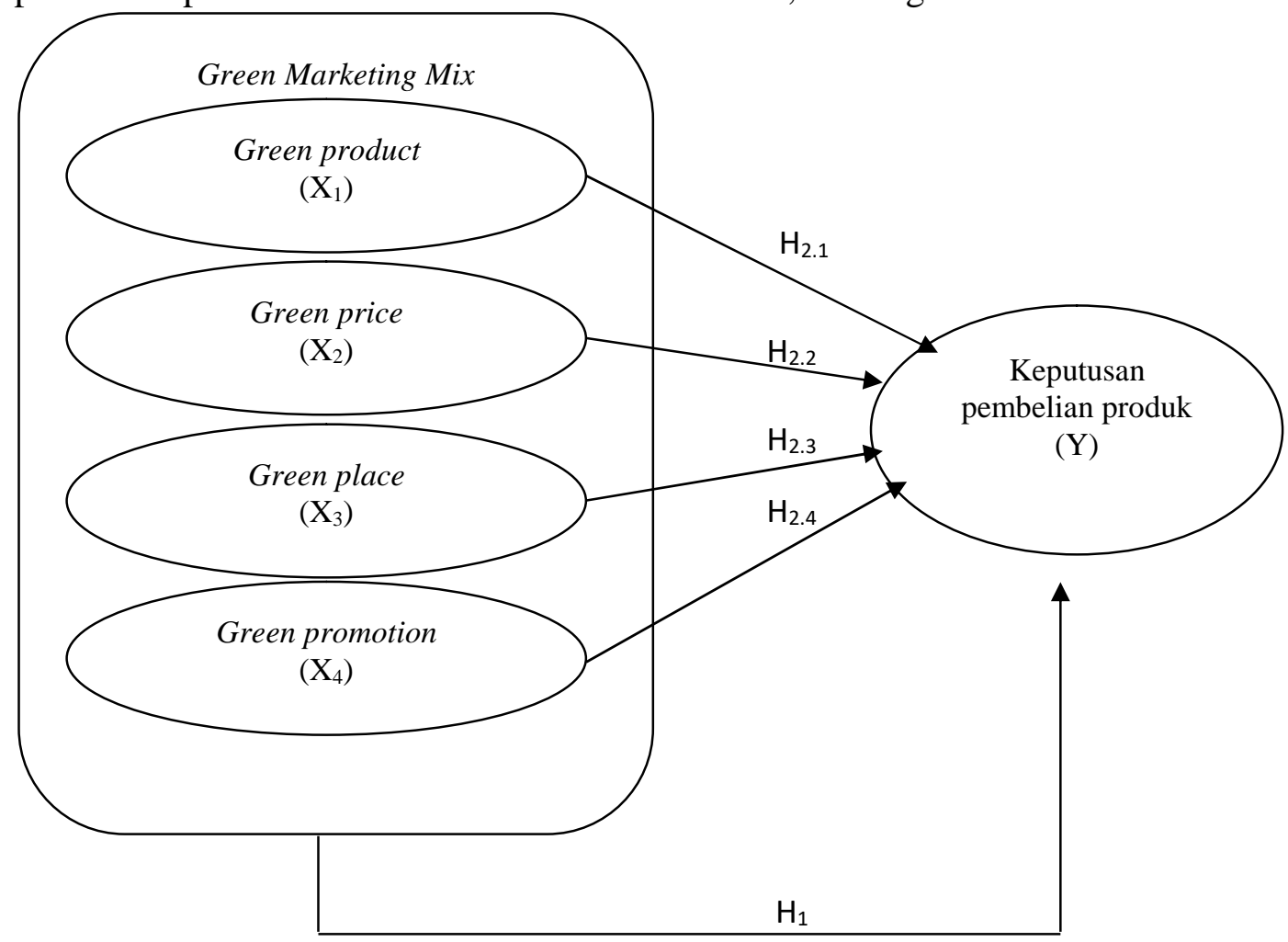

Gambar 1. Kerangka Konseptual

Sumber: Data Diolah, 2018

Gambar 1. menunjukkan bahwa $\mathrm{H}_{1}$ adalah hipotesis yang menjelaskan pengaruh variabel-variabel green marketing mix (green product, green price, green place dan green promotion) secara simultan terhadap keputusan pembelian produk. $\mathrm{H}_{2}$ adalah hipotesis yang menjelaskan pengaruh variabel-variabel green marketing mix (green product, green price, green place dan green promotion) secara parsial terhadap keputusan pembelian produk.

Pemasaran hijau berfokus pada penghematan sumber daya alam dalam produksi, kemasan, dan pengangkutan yang selaras dengan kenyamanan dan keamanan lingkungan (Rehman, 2014). Penentuan hipotesis tentang pengaruh secara simultan green marketing mixterhadap keputusan pembelian produk adalah didasarkan pada telaah kajian penelitian terdahulu.

Hasil penelitian Putripeni (2014) menemukan bahwa secara simultan variabel produk product, price, promotion dan place memiliki pengaruh yang positif dan signifikan terhadap struktur keputusan pembelian. Hasil penelitian Salim (2015) menunjukkan bahwa variabel harga, produk, promosi dan tempat berpengaruh positif dan signifikan secara simultan terhadap keputusan pembelian. Temuan penelitian Syahbandi (2013) menunjukkan bahwaharga, produk, tempat 
dan promosi secara bersama-sama mempunyai pengaruh positif yang signifikan terhadap pilihan konsumen. Penelitian Kampani (2014) menemukan bahwa variabel green marketing berpengaruh langsung dan signifikan terhadap variabel keputusan pembelian. Penelitian Nursyamsi (2013) menunjukkan bahwa strategi green marketing (produk, harga, lokasi, promosi) secara bersama-sama berpengaruh positif dan signifikan terhadap keputusan konsumen dalam membeli rumah.Berdasarkan telaah kajian penelitian terdahulu, maka dapat disusun hipotesis sebagai berikut.

$\mathrm{H}_{1}$ : Variabel-variabel green marketing mix (green product, green price, green place dan green promotion) berpengaruh positif dan signifikan secara simultan terhadap keputusan pembelian produk.

Apa yang membuat suatu produk yang ramah lingkungan mempengaruhi keputusan pembelian produk oleh konsumen, telah menjadi suatu perdebatan serius antara environmentalis, pejabat pemerintah, perusahaan manufaktur dan konsumen. Apakah hanya bahan atau produk telah cukup dianggap menjadi suatu yang ramah lingkungan, ataukah kemasannya yang harus aman. Menurut Queensland Goverment (2002), pengusaha yang ingin mengeksploitasi pasar hijau diharuskan: (1) Mengidentifikasi keinginan pelanggan terhadap lingkungan dan mengembangkan produk sesuai yang pelanggan inginkan, dan (2) mengembangkan tanggung jawab produk yang berwawasan lingkungan agar memiliki pengaruh besar terhadap pesaing. Menurut Rehman (2014) produk hijau mempengaruhi kesadaran pelanggan yang cukup besar untuk bersedia membeli dan membayar untuk produk hijau.

Hasil penelitian Melisa (2014) menunjukkan bahwa green product memberikan pengaruh yang positif dan signifikan terhadap keterlibatan konsumen yang berdampak pada keputusan pembelian konsumen perusahaan Laksmi florist. Penelitian oleh Rahayu (2017) menemukan bahwa green product berpengaruh terhadap keputusan pembelian konsumen, dimana produk yang ramah lingkungan tersebut berhubungan secara positif dengan keputusan pembelian konsumen pada produk tersebut.Hasil penelitian oleh Salim (2015) menunjukkan bahwa ada pengaruh positif dan signifikan antara variabel produk terhadap keputusan pembelian. Putripeni (2014) dalam penelitiannya menunjukkan bahwagreen product memiliki pengaruh positif dan signifikan terhadap struktur keputusan pembelian. Berdasarkan telaah kajian penelitian terdahulu, maka dapat disusun hipotesis sebagai berikut.

$\mathrm{H}_{1}$ : Green product berpengaruh positif dan signifikan terhadap keputusan pembelian produk.

Harga adalah elemen penting dalam green marketing mix.Kebanyakan para pelanggan bersedia membayar dengan harga premium jika ada persepsi tambahan terhadap nilai produk. Peningkatan nilai ini dapat disebabkan oleh kinerja, fungsi, desain, bentuk yang menarik atau kecocokan selera. Keunggulan dari sisi lingkungan hanya merupakan bonus tambahan, tetapi sering kali menjadi faktor yang menentukan antara nilai produk dan kualitas. Produk yang ramah lingkungan sering kali lebih murah jika biaya product life cycle diperhatikan (Queensland Goverment, 2002). 
Penelitian oleh Angeline (2015) menunjukkan bahwa variabel green price memberikan pengaruh terhadap peningkatan persepsi positif pelanggan pada pentingnya menggunakan produk hijau. Hasil penelitian Risyamuka (2015) menunjukkan bahwa secara parsial variabel green priceberpengaruh positif dan signifikan terhadap keputusan pembelian produk hijau. Nursyamsi (2013) dalam penelitiannya menemukan bahwa variabel harga berpengaruh signifikan dan positif terhadap keputusan pembelian konsumen. Temuan penelitian Basil (2013) menunjukkanbahwa adapengaruh yang signifikan antara harga terhadap pilihan konsumen atas sepatu yang dibuatdi Nigeria.Berdasarkan telaah kajian penelitian terdahulu, maka dapat disusun hipotesis sebagai berikut.

$\mathrm{H}_{2}$ : Green price berpengaruh positif dan signifikan terhadap keputusan pembelian produk.

Pilihan dimana dan kapan untuk membuat produk selalu tersedia dapat memberikan pengaruh signifikan pada pelanggan. Sangat sedikit pelanggan yang benar-benar hanya ingin membeli produk karena keramahan lingkungannya saja. Penjual yang ingin mencapai kesuksesan dalam penjualan produk yang ramah lingkungan seharusnya memposisikan produknya secara luas dipasar sehingga dapat lebih dikenali (Queensland Goverment, 2002).

Hasil penelitian Putripeni (2014) menemukan bahwa place memiliki pengaruh yang positif dan signifikan terhadap struktur keputusan pembelian. Temuan penelitian Syahbandi (2013) menunjukkan bahwatempat secara bersamasama mempunyai pengaruh positif yang signifikan terhadap pilihan konsumen. Penelitian Nursyamsi (2013) menunjukkan bahwa strategi lokasi berpengaruh positif dan signifikan terhadap keputusan konsumen dalam membeli rumah. Temuan penelitian Anilkumar (2012) diketahui lokasi berpengaruh signifikan terhadap sikap konsumen dalam pembelian produk dapur. Berdasarkan telaah kajian penelitian terdahulu, maka dapat disusun hipotesis sebagai berikut.

$\mathrm{H}_{3}$ : Green place berpengaruh positif dan signifikan terhadap keputusan pembelian produk.

Mempromosikan suatu produk dan jasa untuk memperoleh pasar dapat dilakukan dengan iklan, public relations, promosi penjualan, direct marketing dan on-site promotions. Penjual produk hijau yang cerdas akan dapat menekankan kredibilitas produk yang ramah lingkungan dengan menggunakan sustainable marketing, juga alat dan praktek komunikasi (Queensland Goverment, 2002).

Melisa (2014) dalam penelitiannya menemukan bahwa promosimelalui green advertising memberikan pengaruh yang positif dan signifikan terhadap keterlibatan konsumen yang berdampak pada keputusan pembelian konsumen perusahaan Laksmi florist.Penelitian yang dilakukan Putripeni (2014) menunjukkan bahwapromosimemiliki pengaruh positif dan signifikan terhadap struktur keputusan pembelian. Sagala (2014) dalam penelitiannya menemukan promosi berpengaruh signifikan terhadap keputusan pembelian konsumen di industri makanan cepat saji. Penelitian Siswanto (2015) menunjukkan kegiatan enviromental advertising berpengaruh positif dan signifikan terhadap minat beli produk. Karbala (2012) menemukan bahwa promosi berkontribusi secara signifikan dalam mempengaruhi konsumen untuk membeli suatu produk di 
Toimoi Store.Berdasarkan telaah kajian penelitian terdahulu, maka dapat disusun hipotesis sebagai berikut.

$\mathrm{H}_{4}$ : Green promotion berpengaruh positif dan signifikan terhadap keputusan pembelian produk.

\section{METODE PENELITIAN}

Penelitian ini menggunakan pendekatan kuantitatif adalah penelitian ilmiah yang sistematis terhadap bagian-bagian dan fenomena serta hubunganhubungannya.Penelitian ini dilaksanakan di Lotus Food Services yang memasarkan dan menjual produk Big Tree Farms, beralamat di Jalan Bypass Ngurah Rai No.18, Jimbaran, Badung. Latar belakang pemilihan lokasi pada penelitian ini adalah Lotus Food Services menjual produk bahan makanan organik yaitu Big Tree Farms yang ramah lingkungan, yang dalam pemasaran produknya menerapkan strategi green marketing mix. Ketatnya persaingan dengan usaha sejenis maka penting diketahui pengaruh green marketing mixterhadap keputusan pembelian produk.

Sebagai objek dalam penelitian adalah bidang pemasaran yaitu green marketing mix (green product, green price, green place dan green promotion) dankeputusan pembelian produk. Variabel bebas dalam penelitian ini adalah elemen-elemengreen marketing mix yaitu: green product $\left(\mathrm{X}_{1}\right)$, green price $\left(\mathrm{X}_{2}\right)$, green place $\left(\mathrm{X}_{3}\right)$ dan green promotion $\left(\mathrm{X}_{4}\right)$. Variabel terikat dalam penelitian ini adalah keputusan pembelian produk (Y).

Keputusan pembelian produk (Y) adalah pilihan akhir yang dilakukan oleh konsumen dari tahapan yang telah dilakukan dalam memenuhi kebutuhan dan keinginannya untuk memutuskan membeli produk Big Tree Farms di Lotus Food ServicesJimbaran, Badung. Indikator-indikatornya adalah sebagai berikut (Rizkia, 2014): Pengenalan kebutuhan, Pencarian informasi, Evaluasi alternatif, Pembelian dan Pasca pembelian.

Green marketing mix $(\mathrm{X})$ adalah kombinasi antara empat macam variabel pemasaran $(4 \mathrm{P})$ hijau terdiri dari green product $\left(\mathrm{X}_{1}\right)$, green price $\left(\mathrm{X}_{2}\right)$, green place $\left(\mathrm{X}_{3}\right)$ dan green promotion $\left(\mathrm{X}_{4}\right)$ yang merupakan alat untuk mempengaruhi perilaku konsumen terhadap keputusan pembelian produk Big Tree Farms di Lotus Food ServicesJimbaran, Badung, yang dalam aktivitasnya memberikan dampak minimal pada perusakan lingkungan alam sehingga dapat meningkatkan kesejahteraan konsumen dan masyarakat.

Green product $\left(\mathrm{X}_{1}\right)$ adalah produk Big Tree Farms di Lotus Food ServicesJimbaran, Badung dibuat dengan upaya untuk meminimalkan limbah negatif ketika proses produksi hingga produk jadi yang sekaligus memenuhi syarat ramah lingkungan. Indikator-indikatornya adalah (Rahayu, 2017): Bahan alami, Produk ramah lingkungan, Daur ulang kemasan, Produk bersertifikasi dan Daya tahan produk. Green price $\left(\mathrm{X}_{2}\right)$ adalah penetapan harga premiun dari produk Big Tree Farms di Lotus Food Services Jimbaran, Badung didasarkan besarnya investasi teknologi dalam membantu riset yang dilakukan untuk menemukan atau menghasil produk berbasis lingkungan. Indikator-indikatornya adalah (Angeline, 2015): Biaya untuk kesehatan, Biaya dengan manfaat lingkungan, Diskon harga, Harga premium dan Harga bersaing. 
Green place $\left(\mathrm{X}_{3}\right)$ adalah tempat penjualan produk Big Tree Farms di Lotus Food ServicesJimbaran, Badungyang ramah lingkungan. Indikator-indikatornya adalah (Angeline, 2015): Lokasi strategis, Lokasi hijau, Kelengkapan produk di setiap outlet, Outlet bertema lingkungan dan Parkir yang nyaman. Green promotion $\left(\mathrm{X}_{4}\right)$ adalah kegiatan promosi yang dilakukan dengan environmental advertisement yaitu melalui media iklan dengan tujuan untuk mempengaruhi dan meyakinkan konsumen terhadap produk Big Tree Farms di Lotus Food ServicesJimbaran, Badung dengan menekankan kepedulian terhadap produk yangramah lingkungan sehingga konsumen menjadi tertarik dan memutuskan untuk membeli produk. Indikator-indikatornya adalah (Siswanto, 2015): Ketepatan media periklanan, Pesan produk ramah lingkungan, Iklan memperkuat image produk, Iklanmenjadi panduan informasi pembelian dan Mempengaruhi loyalitas konsumen.

Data kuantitatif adalah data yang dapat dihitung dan berupa angka-angka seperti data nilai penjualanproduk Big Tree Farms di Lotus Food ServicesJimbaran, Badung serta skor jawaban responden dari hasil kuesioner yang disebarkan.Data kualitatif adalah data yang tidak berbentuk angka-angka melainkan keterangan seperti sejarah singkat berdirinya perusahaan, struktur organisasi, deskripsi jabatan dan aktivitas pemasaranproduk Big Tree Farms di Lotus Food ServicesJimbaran, Badung.Dalam penelitian ini yang termasuk data primer adalah jawaban kuesioner pengaruh green marketing mix terhadap keputusan pembelian produk. Data nilai penjualan produk Big Tree Farms di Lotus Food ServicesJimbaran, Badung, sejarah singkat berdirinya perusahaan, struktur organisasi dan deskripsi jabatan serta aktivitas pemasaranproduk Big Tree Farms di Lotus Food ServicesJimbaran, Badung termasuk data sekunder.

Populasi dalam penelitian ini adalah konsumen yang membeli produk Bening Big Tree Farms melalui Lotus Food ServicesJimbaran, Badung, dengan jumlah populasi yang tidak diketahui dengan jelas. Penelitian ini menggunakan 25 (lima) indikator, sehingga jumlah sampel minimal yang harus digunakan adalah: 25 × $5=125$ orang responden. Mempertimbangkan penggunaan sampel untuk memperoleh data yang mencerminkan keadaan populasi serta keterbatasan kemampuan dan biaya, maka jumlah sampel dalam penelitian ini ditetapkan sebanyak 125 orang konsumen. Sampel dalam penelitian ini ditentukan dengan metode purposive sampling yaitu metode penentuan sampel non-probabilitas dengan beberapa kriteria pertimbangan tertentu (Sugiyono, 2014:122). Kriteria yang dimaksud adalah: 1) sampel adalah konsumen yang sudah pernah menggunakan produk Big Tree Farms di Lotus Food ServicesJimbaran, Badung,dan 2) berusia minimal 21 tahun. Kriteria yang kedua dengan sengaja ditentukan agar responden memahami dengan baik substansi butir-butir pernyataan dalam kuesioner.

Teknik analisis yang digunakan dalam penelitian ini adal teknik analisis regresi linier berganda. Analisis ini digunakan untuk mengetahui pengaruh secara simultan green marketing mix (green product, green price, green place dan green promotion) terhadapkeputusan pembelian produk. Hasil analisis dinyatakan dalam bentuk persamaan regresi linier berganda. 
$\hat{Y} \quad=\beta_{1} X_{1}+\beta_{2} X_{2}+\beta_{3} X_{3}+\beta_{4} X_{4}+$ ei.

Keterangan:

$\hat{\mathrm{Y}} \quad=$ keputusan pembelian produk

$\mathrm{X}_{1}=$ Green product

$\mathrm{X}_{2}=$ Green price

$\mathrm{X}_{3}=$ Green place

$\mathrm{X}_{4}=$ Green promotion

\section{HASIL DAN PEMBAHASAN}

Karakteristik responden dalam penelitian ini dapat dibedakan berdasarkan umur,jenis kelamin, pendidikan, pekerjaan dan pendapatan per bulan. Dilihat dari persentase umur, konsumen yang berusia antara 31 sampai dengan 40 tahun adalah paling banyakdengan persentase terbesar yaitu 50,40\%. Hal ini disebabkan karena rentang usia initermasuk usia yang paling produktif dalam melakukan aktivitas, termasuk dalam pembelian produk. Dilihat dari persentase jenis kelamin, konsumen laki-laki mempunyai persentase yang lebih besar dalam membeli produk Big Tree Farms di Lotus Food Services Jimbaran, Badung yaitu sebanyak 93 orang atau sebesar $74,40 \%$ dibandingkan dengan konsumen perempuan yaitu sebanyak 32 orang atau sebesar 25,60\%. Hal ini dapat dimaklumi karena konsumen laki-laki pada umumnya adalah kepala rumah tangga yang membiayai dan mengurus kebutuhan pribadi dan keluarganya dalam pembelian produk.

Tingkat pendidikan konsumen yang mendominasi dalam membeli produk Big Tree Farmsadalah SMA yaitu sebanyak 56 orang atau sebesar 44,80\%, selanjutnya adalah S1 sebanyak 36 orang atau sebesar 28,80\%, Diploma sebanyak 13 orang atau sebesar $10,40 \%$, S2 sebanyak 11 orang atau sebesar 8,80\%, SMP sebanyak 5 orang atau sebesar 4,00\% dan terakhir adalah SD sebanyak 4 orang atau sebesar 3,20\%.Hal ini adalah berdasarkan data yang didapat dari penyebaran kuesioner, diketahui tingkat pendidikan konsumen yang membeli produk Big Tree Farms di Lotus Food Services Jimbaran, Badungsebagian besar adalah SMA.

Dilihat dari persentase jenis pekerjaan, konsumen yang bekerja sebagai pegawai swasta mempunyai persentase terbanyak dalam membeli produk Big Tree Farms di Lotus Food Services Jimbaran, Badungyaitu sebesar 30,40\%. Hal ini adalah berdasarkan data yang didapat dari penyebaran kuesioner diketahui pekerjaan terbanyak dari konsumen adalah bekerja di sektor swasta. Ditinjau dari pendapatan diketahui responden dengan pendapatan Rp.3.000.000,- sampai Rp.5.000.000,- per bulanadalah yang terbanyak yaitu 47 orang atau sebesar $37,60 \%$, selanjutnya pendapatan kurang dari Rp.3.000.000,- per bulan adalah 45 orang atau sebesar $36,00 \%$ dan pendapatan lebih dari Rp.5.000.000,- per bulan sebanyak 33 orang atau sebesar $26,40 \%$. Hal ini menunjukkan konsumen dengan 
pendapatan Rp.3.000.000,- sampai Rp.5.000.000,- per bulan sudah termasuk kategori memadai untuk membeli produk Big Tree Farms di Lotus Food Services Jimbaran, Badung.

Tabel 1.

Hasil Uji Validitas Instrumen Penelitian

\begin{tabular}{|c|c|c|c|c|c|}
\hline No & Variabel & $\begin{array}{c}\text { Item } \\
\text { Pernyataan }\end{array}$ & $\begin{array}{l}\text { Koefisien } \\
\text { Korelasi }\end{array}$ & $\begin{array}{c}\text { Validitas } \\
\text { Syarat } \\
\text { Valid }\end{array}$ & Keterangan \\
\hline \multirow[t]{5}{*}{1} & \multirow{5}{*}{$\begin{array}{l}\text { Keputusan pembelian } \\
\text { produk } \\
\left(\mathrm{X}_{1}\right)\end{array}$} & $\mathrm{Y}_{1}$ & 0,814 & $>0,30$ & Valid \\
\hline & & $\mathrm{Y}_{2}$ & 0,802 & $>0,30$ & Valid \\
\hline & & $\mathrm{Y}_{3}$ & 0,437 & $>0,30$ & Valid \\
\hline & & $\mathrm{Y}_{4}$ & 0,622 & $>0,30$ & Valid \\
\hline & & $\mathrm{Y}_{5}$ & 0,706 & $>0,30$ & Valid \\
\hline \multirow[t]{5}{*}{2} & \multirow{5}{*}{$\begin{array}{l}\text { Green product } \\
\left(\mathrm{X}_{1}\right)\end{array}$} & $\mathrm{X}_{1.1}$ & 0,858 & $>0,30$ & Valid \\
\hline & & $\mathrm{X}_{1.2}$ & 0,860 & $>0,30$ & Valid \\
\hline & & $\mathrm{X}_{1.3}$ & 0,564 & $>0,30$ & Valid \\
\hline & & $\mathrm{X}_{1.4}$ & 0,552 & $>0,30$ & Valid \\
\hline & & $\mathrm{X}_{1.5}$ & 0,670 & $>0,30$ & Valid \\
\hline \multirow[t]{5}{*}{3} & \multirow{5}{*}{$\begin{array}{l}\text { Green price } \\
\left(\mathrm{X}_{2}\right)\end{array}$} & $\mathrm{X}_{2.1}$ & 0,782 & $>0,30$ & Valid \\
\hline & & $\mathrm{X}_{2.2}$ & 0,847 & $>0,30$ & Valid \\
\hline & & $\mathrm{X}_{2.3}$ & 0,833 & $>0,30$ & Valid \\
\hline & & $\mathrm{X}_{2.4}$ & 0,818 & $>0,30$ & Valid \\
\hline & & $\mathrm{X}_{2.5}$ & 0,764 & $>0,30$ & Valid \\
\hline \multirow[t]{5}{*}{4} & \multirow[t]{5}{*}{ Green place $\left(\mathrm{X}_{3}\right)$} & $\mathrm{X}_{3.1}$ & 0,900 & $>0,30$ & Valid \\
\hline & & $\mathrm{X}_{3.2}$ & 0,798 & $>0,30$ & Valid \\
\hline & & $\mathrm{X}_{3.3}$ & 0,705 & $>0,30$ & Valid \\
\hline & & $\mathrm{X}_{3.4}$ & 0,722 & $>0,30$ & Valid \\
\hline & & $\mathrm{X}_{3.5}$ & 0,643 & $>0,30$ & Valid \\
\hline \multirow[t]{5}{*}{5} & \multirow[t]{5}{*}{ Green promotion $\left(\mathrm{X}_{4}\right)$} & $\mathrm{X}_{4.1}$ & 0,638 & $>0,30$ & Valid \\
\hline & & $\mathrm{X}_{4.2}$ & 0,874 & $>0,30$ & Valid \\
\hline & & $\mathrm{X}_{4.3}$ & 0,818 & $>0,30$ & Valid \\
\hline & & $\mathrm{X}_{4.4}$ & 0,665 & $>0,30$ & Valid \\
\hline & & $\mathrm{X}_{4.5}$ & 0,823 & $>0,30$ & Valid \\
\hline
\end{tabular}

Sumber: Data Diolah, 2018

Pengujian validitas masing-masing instrumen penelitian yang diperoleh dari jawaban kuesioner sangat penting dilakukan untuk memperoleh hasil penelitian yang valid. Suatu instrumen dikatakan valid atau sah apabila memiliki koefisien 
korelasi pearson product moment (r)antara item dengan skor total lebih besar dari 0,30 . Hasil uji validitas instrumen penelitian, dapat dilihat pada Tabel 1 . Tabel 1 menunjukkan bahwa instrumen penelitian pada variabel keputusan pembelian produk $(\mathrm{Y})$, green product $\left(\mathrm{X}_{1}\right)$, green price $\left(\mathrm{X}_{2}\right)$, green place $\left(\mathrm{X}_{3}\right)$ dan green promotion $\left(\mathrm{X}_{4}\right)$ seluruhnya adalah valid. Dikatakan valid karena semua instrumen penelitian mempunyai koefisien korelasi pearson product moment $(\mathrm{r})$ lebih besar dari 0,30 . Hal ini berarti instrumen penelitian yang digunakan adalah sah yaitu pernyataan-pernyataan pada kuesioner mampu mengungkapkan apa yang diukur oleh kuesioner tersebut.

Tabel 2.

\section{Hasil Uji Reliabilitas Instrumen Penelitian}

\begin{tabular}{lccc}
\hline \multicolumn{1}{c}{ Variabel } & $\begin{array}{c}\text { Cronbach's } \\
\text { Alpha }\end{array}$ & $\begin{array}{c}\text { Syarat } \\
\text { Reliable }\end{array}$ & Keterangan \\
\hline Keputusan pembelian produk $\left(\mathrm{X}_{1}\right)$ & 0,719 & $>0,60$ & Reliable \\
Green product $\left(\mathrm{X}_{1}\right)$ & 0,749 & $>0,60$ & Reliable \\
Green price $\left(\mathrm{X}_{2}\right)$ & 0,863 & $>0,60$ & Reliable \\
Green place $\left(\mathrm{X}_{3}\right)$ & 0,808 & $>0,60$ & Reliable \\
Green promotion $\left(\mathrm{X}_{4}\right)$ & 0,826 & $>0,60$ & Reliable \\
\hline
\end{tabular}

Sumber: Data Diolah, 2018

Tabel 2. menunjukkan bahwa instrumen penelitian pada variabel keputusan pembelian produk $(\mathrm{Y})$, green product $\left(\mathrm{X}_{1}\right)$, green price $\left(\mathrm{X}_{2}\right)$, green place $\left(\mathrm{X}_{3}\right)$ dan green promotion $\left(\mathrm{X}_{4}\right)$ seluruhnya adalah reliable. Dikatakan reliable karena semua instrumen penelitian mempunyai koefisien Cronbach's alpha lebih besar dari 0,70 . Hal ini berarti seluruh instrumen penelitian adalah reliabel atau handal karena jawaban tiap responden dianggap konsisten atau stabil dari waktu ke waktu.

Tabel 3. dapat dijelaskan bahwa distribusi frekuensi jawaban responden dari 5 indikator variabel keputusan pembelian produk tergolong dalam kategori baik dengan rata-rata skor 3,42, meskipun demikian masih ada dua indikator yang dianggap belum baik dengan kategori cukup baik, yaitu Pengenalan Kebutuhan dan Pencarian Informasi.

Green product merupakan variabel bebas yang disimbolkan dengan $\left(\mathrm{X}_{1}\right)$ adalah produk Big Tree Farms di Lotus Food ServicesJimbaran, Badung dibuat dengan upaya untuk meminimalkan limbah negatif ketika proses produksi hingga produk jadi yang sekaligus memenuhi syarat ramah lingkungan. Variabel green product diukur dari 5 indikator. Indikator-indikator tersebut disusun dalam kuesioner untuk dijawab oleh responden.

Tabel 4. dapat dijelaskan bahwa distribusi frekuensi jawaban responden dari 5 indikator variabel green product tergolong dalam kategori baik dengan rata-rata skor 3,56, meskipun demikian masih ada satu indikator yang dianggap belum baik dengan kategori cukup baik, yaitu Bahan Alami. 
Tabel 3.

Distribusi Frekuensi Jawaban Indikator Keputusan Pembelian

\begin{tabular}{|c|c|c|c|c|c|c|c|c|c|}
\hline \multirow[b]{2}{*}{ No } & \multicolumn{7}{|c|}{ Frekuensi Jawaban } & \multirow{2}{*}{$\begin{array}{l}\text { Rata } \\
\text {-rata } \\
\text { Skor }\end{array}$} & \multirow{2}{*}{$\begin{array}{l}\text { Kategor } \\
\text { i } \\
\text { Penilaia } \\
\text { n }\end{array}$} \\
\hline & Indikator & $\begin{array}{c}\text { ST } \\
\text { S }\end{array}$ & TS & CS & $\mathbf{S}$ & SS & $\begin{array}{l}\text { Total } \\
\text { Skor }\end{array}$ & & \\
\hline 1 & Pengenalan kebutuhan. & 0 & 29 & 68 & 28 & 0 & 374 & 2,99 & $\begin{array}{l}\text { Cukup } \\
\text { Baik }\end{array}$ \\
\hline 2 & Pencarian informasi. & 0 & 18 & 57 & 42 & 8 & 415 & 3,32 & $\begin{array}{l}\text { Cukup } \\
\text { baik }\end{array}$ \\
\hline 3 & Evaluasi alternatif. & 0 & 0 & 53 & 62 & 10 & 457 & 3,66 & Baik \\
\hline 4 & Pembelian. & 0 & 5 & 67 & 43 & 10 & 433 & 3,46 & Baik \\
\hline 5 & Pasca pembelian. & 0 & 3 & 42 & 69 & 11 & 463 & 3,70 & Baik \\
\hline \multicolumn{7}{|c|}{ Jumlah Skor } & 2142 & 17,1 & \\
\hline \multicolumn{7}{|c|}{ Rata-rata Skor } & 428,4 & 3,42 & Baik \\
\hline
\end{tabular}

Sumber: Data Diolah, 2018

Tabel 4.

Distribusi Frekuensi Jawaban Indikator Green Product

\begin{tabular}{|c|c|c|c|c|c|c|c|c|c|}
\hline \multirow[b]{2}{*}{ No } & \multirow[b]{2}{*}{ Indikator } & \multicolumn{5}{|c|}{ Frekuensi Jawaban } & \multirow{2}{*}{$\begin{array}{l}\text { Total } \\
\text { Skor }\end{array}$} & \multirow{2}{*}{$\begin{array}{l}\text { Rata- } \\
\text { rata } \\
\text { Skor }\end{array}$} & \multirow{2}{*}{$\begin{array}{l}\text { Kategori } \\
\text { Penilaia } \\
\text { n }\end{array}$} \\
\hline & & $\begin{array}{l}\text { ST } \\
\text { S }\end{array}$ & TS & CS & $\mathbf{S}$ & SS & & & \\
\hline 1 & Bahan alami. & 0 & 14 & 68 & 43 & 0 & 404 & 3,23 & $\begin{array}{l}\text { Cukup } \\
\text { Baik }\end{array}$ \\
\hline 2 & $\begin{array}{l}\text { Produk ramah } \\
\text { lingkungan. }\end{array}$ & 0 & 9 & 33 & 66 & 17 & 466 & 3,73 & Baik \\
\hline 3 & Daur ulang kemasan. & 0 & 0 & 67 & 47 & 11 & 444 & 3,55 & Baik \\
\hline 4 & Produk bersertifikasi. & 0 & 3 & 61 & 55 & 6 & 439 & 3,51 & Baik \\
\hline 5 & Daya tahan produk. & 0 & 5 & 42 & 51 & 27 & 475 & 3,80 & Baik \\
\hline \multicolumn{7}{|c|}{ Jumlah Skor } & $\begin{array}{l}2228 \\
445,6\end{array}$ & $\begin{array}{l}17,8 \\
3,56\end{array}$ & Baik \\
\hline
\end{tabular}

Sumber: Data Diolah, 2018

Tabel 5. dapat dijelaskan bahwa distribusi frekuensi jawaban responden dari 5 indikator variabel green price tergolong dalam kategori baik dengan rata-rata skor 3,56, meskipun demikian masih ada satu indikator yang dianggap belum baik dengan kategori cukup baik, yaitu Biaya Untuk Kesehatan.

Tabel 6. dapat dijelaskan bahwa distribusi frekuensi jawaban responden dari 5 indikator variabel green place tergolong dalam kategori baik dengan rata-rata skor 3,54, dua kategori cukup baik, yaitu lokasi strategis dan lokasi hijau.

Tabel 7. dapat dijelaskan bahwa distribusi frekuensi jawaban responden dari 5 indikator variabel green promotion tergolong dalam kategori baik dengan ratarata skor 3,52, meskipun demikian masih ada satu indikator yang dianggap belum baik dengan kategori cukup baik, yaitu ketepatan media periklanan. 
Tabel 5.

Distribusi Frekuensi Jawaban Indikator Green Price

\begin{tabular}{|c|c|c|c|c|c|c|c|c|c|}
\hline \multirow[b]{2}{*}{ No } & \multirow[b]{2}{*}{ Indikator } & \multicolumn{5}{|c|}{ Frekuensi Jawaban } & \multirow{2}{*}{$\begin{array}{l}\text { Total } \\
\text { Skor }\end{array}$} & \multirow{2}{*}{$\begin{array}{l}\text { Rata- } \\
\text { rata } \\
\text { Skor }\end{array}$} & \multirow{2}{*}{$\begin{array}{l}\text { Kategori } \\
\text { Penilaian }\end{array}$} \\
\hline & & $\begin{array}{c}\text { ST } \\
\text { S }\end{array}$ & TS & CS & $\mathbf{S}$ & SS & & & \\
\hline 1 & Biaya untuk kesehatan. & 0 & 13 & 73 & 38 & 1 & 402 & 3,22 & $\begin{array}{l}\text { Cukup } \\
\text { baik }\end{array}$ \\
\hline 2 & $\begin{array}{l}\text { Biaya dengan manfaat } \\
\text { lingkungan. }\end{array}$ & 0 & 10 & 39 & 64 & 12 & 453 & 3,62 & Baik \\
\hline 3 & Diskon harga. & 0 & 0 & 54 & 54 & 17 & 463 & 3,70 & Baik \\
\hline 4 & Harga premium. & 0 & 3 & 65 & 51 & 6 & 435 & 3,48 & Baik \\
\hline 5 & Harga bersaing. & 0 & 5 & 39 & 54 & 27 & 468 & 3,74 & Baik \\
\hline \multicolumn{7}{|c|}{$\begin{array}{l}\text { Jumlah Skor } \\
\text { Rata-rata Skor }\end{array}$} & $\begin{array}{l}2221 \\
444,2\end{array}$ & $\begin{array}{l}17,8 \\
3,56\end{array}$ & Baik \\
\hline
\end{tabular}

Sumber: Data Diolah, 2018

Tabel 6.

Distribusi Frekuensi Jawaban Indikator Green Place

\begin{tabular}{|c|c|c|c|c|c|c|c|c|c|}
\hline \multirow[b]{2}{*}{ No } & \multicolumn{6}{|c|}{ Frekuensi Jawaban } & \multirow{2}{*}{$\begin{array}{l}\text { Total } \\
\text { Skor }\end{array}$} & \multirow{2}{*}{$\begin{array}{l}\text { Rata- } \\
\text { rata } \\
\text { Skor }\end{array}$} & \multirow{2}{*}{$\begin{array}{l}\text { Kategori } \\
\text { Penilaia } \\
\text { n }\end{array}$} \\
\hline & Indikator & $\begin{array}{l}\text { ST } \\
\text { S }\end{array}$ & TS & CS & $\mathbf{S}$ & SS & & & \\
\hline 1 & $\begin{array}{l}\text { Green place } \\
\text { Lokasi strategis. }\end{array}$ & 0 & 12 & 62 & 46 & 5 & 419 & 3,35 & $\begin{array}{l}\text { CukupBa } \\
\text { ik }\end{array}$ \\
\hline 2 & Lokasi hijau. & 0 & 14 & 61 & 45 & 5 & 416 & 3,33 & $\begin{array}{l}\text { Cukup } \\
\text { Baik }\end{array}$ \\
\hline 3 & Kelengkapan produk. & 0 & 5 & 38 & 58 & 24 & 476 & 3,81 & Baik \\
\hline 4 & $\begin{array}{l}\text { Outlet bertema } \\
\text { lingkungan. }\end{array}$ & 0 & 12 & 38 & 58 & 17 & 455 & 3,64 & Baik \\
\hline 5 & Parkir yang nyaman. & 0 & 9 & 47 & 59 & 10 & 445 & 3,56 & Baik \\
\hline \multicolumn{7}{|c|}{$\begin{array}{l}\text { Jumlah Skor } \\
\text { Rata-rata Skor }\end{array}$} & $\begin{array}{l}2211 \\
442,2\end{array}$ & $\begin{array}{l}17,7 \\
3,54\end{array}$ & Baik \\
\hline
\end{tabular}

Sumber: Data Diolah, 2018

Persamaan regresi linier berganda berdasarkan Tabel 4.9 diperoleh: $\hat{Y}=$ $3,722+0,317 \mathrm{X}_{1}+0,205 \mathrm{X}_{2}+0,148 \mathrm{X}_{3}+0,084 \mathrm{X}_{4}$ menjelaskan bahwa ada pengaruh yang positif secara simultan green marketing mix (green product, green price, green place dan green promotion) terhadap keputusan pembelian produk Big Tree Farms di Lotus Food ServicesJimbaran, Badung. Koefisien regresi bertanda positif berarti ada pengaruh yang searah, di mana jika green product, green price, green place dan green promotion semakin meningkat maka akan diikuti oleh menguatnya keputusan pembelian produk.

Nilai koefisien determinasi dengan $\mathrm{R}^{2}$ sebesar 0,682 menunjukkan bahwa kontribusi secara simultan antara perubahan green marketing mix (green product, green price, green place dan green promotion) terhadap keputusan pembelian produk Big Tree Farms di Lotus Food ServicesJimbaran, Badungadalah sebesar 
68,20 persen, sedangkan sisanya 31,80 persen dijelaskan oleh variabel lain di luar perubahan variabel green marketing mixyang tidak dibahas dalam penelitian ini.

Tabel 7.

Distribusi Frekuensi Jawaban Indikator Green Promotion

\begin{tabular}{|c|c|c|c|c|c|c|c|c|c|}
\hline \multirow[b]{2}{*}{ No } & \multirow[b]{2}{*}{ Indikator } & \multicolumn{5}{|c|}{ Frekuensi Jawaban } & \multirow[b]{2}{*}{$\begin{array}{l}\text { Total } \\
\text { Skor }\end{array}$} & \multirow{2}{*}{$\begin{array}{l}\text { Rata- } \\
\text { rata } \\
\text { Skor }\end{array}$} & \multirow{2}{*}{$\begin{array}{l}\text { Kategori } \\
\text { Penilaia } \\
\text { n }\end{array}$} \\
\hline & & $\begin{array}{l}\text { ST } \\
\text { S }\end{array}$ & TS & CS & $\mathbf{S}$ & SS & & & \\
\hline 1 & $\begin{array}{l}\text { Ketepatan media } \\
\text { periklanan. }\end{array}$ & 0 & 21 & 71 & 33 & 0 & 387 & 3,10 & $\begin{array}{l}\text { Cukup } \\
\text { Baik }\end{array}$ \\
\hline 2 & $\begin{array}{l}\text { Pesan produk ramah } \\
\text { lingkungan. }\end{array}$ & 0 & 7 & 42 & 63 & 13 & 457 & 3,66 & Baik \\
\hline 3 & $\begin{array}{l}\text { Iklan memperkuat } \\
\text { image produk. }\end{array}$ & 0 & 0 & 59 & 49 & 17 & 458 & 3,66 & Baik \\
\hline 4 & $\begin{array}{l}\text { Iklanmenjadi panduan } \\
\text { informasi. }\end{array}$ & 0 & 9 & 55 & 51 & 10 & 437 & 3,50 & Baik \\
\hline 5 & $\begin{array}{l}\text { Mempengaruhi } \\
\text { loyalitas konsumen. }\end{array}$ & 0 & 7 & 42 & 59 & 17 & 461 & 3,69 & Baik \\
\hline \multicolumn{7}{|c|}{ Jumlah Skor } & 2200 & 17,6 & \\
\hline \multicolumn{7}{|c|}{ Rata-rata Skor } & 440 & 3,52 & Baik \\
\hline
\end{tabular}

Sumber: Data Diolah, 2018

Tabel 8.

Hasil Analisis Regresi Linier Berganda

\begin{tabular}{lccccc}
\hline \multicolumn{1}{c}{ Model } & \multicolumn{2}{c}{$\begin{array}{c}\text { Unstandardized } \\
\text { Coeficients }\end{array}$} & $\begin{array}{c}\text { Standardized } \\
\text { Coeficients }\end{array}$ & T & Sig. \\
& B & Std. Error & Beta & & \\
\hline Konstanta & 3,722 & 2,683 & & 1,387 & 0,008 \\
Green product $\left(\mathrm{X}_{1}\right)$ & 0,317 & 0,082 & 0,323 & 3,862 & 0,000 \\
Green price $\left(\mathrm{X}_{2}\right)$ & 0,205 & 0,083 & 0,211 & 2,462 & 0,015 \\
Green place $\left(\mathrm{X}_{3}\right)$ & 0,148 & 0,077 & 0,163 & 1,918 & 0,047 \\
Green promotion $\left(\mathrm{X}_{4}\right)$ & 0,084 & 0,087 & 0,084 & 0,970 & 0,034 \\
$\mathrm{R}$ & $=0,827$ & & & & \\
$\mathrm{R}$ Square $\left(\mathrm{R}^{2}\right)$ & $=0,682$ & & & &
\end{tabular}

Nilai VIF dibawah 10 dan nilai Tolerance dibawah 1 menjelaskan tidak terjadi multikolinearitas atau tidak terjadi korelasi diantara variabel keputusan pembelian produkdan green marketing mix (green product, green price, green place dan green promotion).Koefisien regresi nilai absolut residual tidak signifikan, sehingga tidak terjadi heteroskedastisitas pada variabel keputusan pembelian produkdan green marketing mix (green product, green price, green place dan green promotion). Nilai Asymp. Sig (2-tailed) sebesar 0,200 lebih besar dari 0,05 . Hal ini menjelaskan bahwa model regresi sudah memenuhi asumsi normalitas atau data berdistribusi normal.

F-hitung adalah 6,694dengan nilai signifikansi $\mathrm{F}$ sebesar 0,000 lebih kecil dari 5 persen $(\alpha=0,05)$, berarti ada pengaruh positif dan signifikan secara simultan green marketing mix (green product, green price, green place dan green 
promotion) terhadapkeputusan pembelian produkBig Tree Farms di Lotus Food ServicesJimbaran, Badung.

Hasil t-test berdasarkan Tabel 8diperoleh sebagai berikut: 1)t $\mathrm{t}_{1}$-hitung adalah3,862 dengan nilai signifikansi $\mathrm{t}_{1}$ sebesar 0,000 lebih kecil dari 5 persen $(\alpha$ $=0,05)$, berarti ada pengaruh positif dan signifikan green product terhadapkeputusan pembelian produkBig Tree Farms di Lotus Food ServicesJimbaran, Badung. 2) $\mathrm{t}_{2}$-hitung adalah 2,462dengan nilai signifikansi $\mathrm{t}_{2}$ sebesar 0,015 lebih kecil dari 5 persen $(\alpha=0,05)$, berarti ada pengaruh positif dan signifikan green price terhadapkeputusan pembelian produkBig Tree Farms di Lotus Food ServicesJimbaran, Badung. 3)t 3 -hitung adalah 1,918dengan nilai signifikansi $t_{3}$ sebesar 0,047 lebih kecil dari 5 persen $(\alpha=0,05)$, berarti ada pengaruh positif dan signifikan green place terhadapkeputusan pembelian produkBig Tree Farms di Lotus Food ServicesJimbaran, Badung. 4)t 4 -hitung adalah 0,084 dengan nilai signifikansi $\mathrm{t}_{1}$ sebesar 0,034 lebih kecil dari 5 persen $(\alpha$ $=0,05)$, berarti ada pengaruh positif dan signifikan green promotion terhadapkeputusan pembelian produkBig Tree Farms di Lotus Food ServicesJimbaran, Badung.

Koefisien Beta green product $\left(\beta_{1}\right)$ adalah 0,323 (ranking 1 ) lebih besar dari koefisien Beta green price $\left(\beta_{2}\right)$ adalah 0,211 (ranking 2 ), koefisien Beta green place $\left(\beta_{3}\right)$ adalah 0,163 (ranking 3 ) dan koefisien Beta green promotion $\left(\beta_{4}\right)$ adalah 0,084 (ranking 4), menunjukkan variabel green product mempunyai pengaruh dominan terhadap terhadapkeputusan pembelian produkBig Tree Farms di Lotus Food ServicesJimbaran, Badung.

\section{SIMPULAN}

Berdasarkan hasil pembahasan, didapat simpulan hasil penelitian adalah sebagai berikut: Berdasarkan hasil analisis data serta pembahasan mengenai pengaruh masing-masing variabel yang telah dipaparkan, maka dapat ditarik kesimpulan sebagai berikut: 1) Green marketing mix (green product, green price, green place dan green promotion) berpengaruh positif dan signifikan secara simultan terhadap keputusan pembelian produk Big Tree Farms di Lotus Food ServicesJimbaran, Badung. 2) Green marketing mix (green product, green price, green place dan green promotion) berpengaruh positif dan signifikan secara parsial terhadap keputusan pembelian produk Big Tree Farms di Lotus Food ServicesJimbaran, Badung. 3) Green product berpengaruh dominan terhadap keputusan pembelian produk Big Tree Farms di Lotus Food ServicesJimbaran, Badung.

Berdasarkan temuan penelitian, maka saran yang dapat diajukan bagi manajemen perusahaan adalah sebagai berikut: 1) Keputusan pembelian produk ditingkatkan dengan cara menambah pengenalan kebutuhan konsumen akan produk dan proses pencarian informasi mengenai produk yang dibuthkan sehingga dihadapkan sehingga konsumen dapat mengenal produk terlebih dahulu sebelum memutuskan membeli produk Big Tree Farms di Lotus Food ServicesJimbaran, Badung. 2) Green product ditingkatkan dengan meningkatkan kualitas produk menggunakan bahan yang lebih alami sehingga lebih menarik dan memberikan informasi kepada konsumen dalam usaha meningkatkan kesadaran konsumen 
akan kesehatan. 3) Green price ditingkatkan dengan lebih meningkatan kesadaran konsumen akan harga yang harus dibayar untuk kesehatan terutama untuk pembelian produk Big Tree Farms di Lotus Food ServicesJimbaran, Badung. Sehingga konsumen dapat menyadari manfaat produk bagi kesehatan dan rela untuk menukarkannya dengan harga yang sesuai. 4) Green place ditingkatkan dengan cara memperhijaulokasir dan menambah pohon perindang pada area parkir sehingga lebih memberikan kesan hijau dan memberikan kenyamanan bagi konsumen saat berbelanja. 5) Green promotion ditingkatkan dengan cara lebih teliti dalam pemilhan media sebagai tempat mengiklankan produkBig Tree Farms di Lotus Food Services Jimbaran, Badung agar iklan dapat menyentuh target segmen yang dibutuhkan oleh perusahaan. 6) Penelitian selanjutnya dapat menjadikan penelitian ini sebagai referensi dengan menggunakan atau menambah variabel lain yang berpengaruh terhadap keputusan konsumen dalam membeli produk sehingga dapat diketahui lebih mendalam variabel-variabel yang dapat mempengaruhi niat konsumen dalam membeli produk, seperti bauran pemasaran, kualitas pelayanan dan brand equity (kualitas merek). Disarankan juga bagi penelitian selanjutnya untuk menambah jumlah sampel dan melakukan penelitian pada sektor usaha yang lain.

\section{REFERENSI}

Agustin, Risna Dwi. 2015. Pengaruh Green Marketing Terhadap Minat Beli Serta Dampaknya pada Keputusan Pembelian (Survei pada Konsumen NonMember Tupperware di Kota Malang). Jurnal Administrasi Bisnis (JAB) 22 (2), hal:1-10.

Akter, Jesmin. 2012. Consumer Attitude Towards Green Marketing in Bangladesh. ASA University Review 6 (1), pp: 157-166.

Angeline, Magdalena Elisabeth. 2015. Hubungan Green Marketing Terhadap Pilihan Konsumen (Studi Kasus pada The Body Shop Manado). Jurnal Jurusan Sosial Ekonomi Fakultas Pertanian Universitas Sam Ratulangi Manado 3 (5), hal: 1-25.

Anilkumar. 2012. The Influence of Marketing on Consumer Attitude Functions for Kitchenware, a Study With Special Reference to Kochi Metro. International Journal of Research in Commerce and Management Vol.3 No.7, pp.32-38.

Assauri, Sofjan.2012.Manajemen Pemasaran Dasar,Konsepdan Strategi.Jakarta: Raja Grafindo Persada.

Awan, Usama. 2013. Green Consumer Behavior: Empirical Study of Swedish Consumer Behavior. Recent Researches in Economics, pp: 89-104.

Bagheri, Hesamoddin. 2013. Surveying The Impact of Green Product on Consumers Buying Decision Process: Case Study of Consumers of Energy 
Saving Bulbs. African Journal of Business Management 7(23), pp: 2266-2270.

Balawera, Asrianto. 2013. Green Marketing dan Corporate Social Responsibility Pengaruhnya Terhadap Keputusan Pembelian Konsumen Melalui Minat Membeli Produk Organik di Freshmart Kota Manado. Jurnal EMBA 1 (4), hal: 2117-2129.

Basil, Glory. 2013. The Marketing Mix Element as Determinants of Consumer's Choice of Made-In-Nigeria Shoes in Cross River State. European Journal of Business and Management Vol.3 No.6, pp.141-148.

Bhatia, Mayank. 2013. Green Marketing: A Study of Consumer Perception and Preferences in India. Electronic Green Journal, 1(36), pp: 1-20.

Boztepe, Aysel. 2012. Green Marketing and Its Impact on Consumer Buying Behavior. European Journal of Economic and Political Studies 5 (1), pp: 5-21.

Dahlstrom, Roberts. 2011. Green Marketing Management. South-Western, Cengage Learning.

Ghozali, Imam. 2013.Aplikasi Analisis Multivariat dengan Program IBM SPSS 21 Upadate PLS Regresi. Semarang: Badan Penerbit Universitas Diponegoro.

Gilaninia, Shahram. 2013. Marketing Mix and Consumer Behavior. Kuwait Chapter of Arabian Journal of Business and Management Review Vol.2 No.12, pp.53-58.

Hanifah, Ayu Devi. 2016. Pengaruh Bauran Pemasaran Berwawasan Green Marketing Terhadap Keputusan Pembelian (Survei pada Pembeli yang Menghuni Perumahan Ijen Nirwana Malang). Jurnal Administrasi Bisnis (JAB) 32 (2), hal: 23-32.

Hariyani, Reni. 2013. Praktik Green Marketing pada Perusahaan-Perusahaan di Indonesia. Jurnal Fakultas Ekonomi Universitas Budi Luhur Jakarta, hal: $1-20$.

Hashem, Tareq N. 2011. The Influence of Applying Green Marketing Mix by Chemical Industries Companies in Three Arab States in West Asia on Consumers Mental Image. International Journal of Business and Social Science 2 (3), pp: 93-101.

Hello, Ghada Mohiuddin. 2014. Green Marketing and Its Relationship to The Purchase Decision: an Empirical Study on Students From King Abdul Aziz University in Jeddah. Journal of Arts, Science and Commerce 5 (2), pp: 121-130. 
Irfan, Mohmed. 2014. Green Marketing Mix Strategies of Consumer Durables with Reference to Automobile Sector. International Journal of Emerging Research in Management and Technology 3 (6), pp: 56-60.

Jaolis, Ferry. 2011. Profil Green Consumers Indonesia: Identifikasi Segmen dan Faktor-Faktor yang Mempengaruhi Perilaku Pembelian Green Products. Jurnal Mitra Ekonomi dan Manajemen Bisnis 2 (1), hal: 18-39.

Kampani, Poppy. 2014. Pengaruh Green Marketing Terhadap Nilai yang Dipersepsikan Dalam Keputusan Pembelian Mobil (Studi pada Konsumen PT Astra International Tbk-TSO Malang Sutoyo). Jurnal Administrasi Bisnis (JAB) 12 (1), hal: 1-8.

Karbala, Ayu. 2012. Analyzing The Factors That Affecting Consumer's Purchase Intention in Toimoi Store, Indonesia. 2nd International Conference on Business, Economics, Management and Behavioral Sciences (BEMBS'2012) Oct. 13-14, 2012 Bali (Indonesia), pp.80-83.

Kotler, Philip dan Gary Armstrong.2012.Prinsip-Prinsip PemasaranJilid 1. Jakarta: Erlangga.

Kotler, Philip dan Kevin Keller. 2013.Manajemen PemasaranJilid 1. Jakarta: Erlangga.

Leonidou, Constantinos N. 2014. Greening The Marketing Mix: Do Firms Do It and Does It Pay Off?. Journal of the Academy of Marketing Science 41 (2), pp: $1-52$.

Maharani, Nina. 2012. Aktivitas Green Marketing yang Dilakukan Oleh Produsen dan Toko. Jurnal Sosial, Ekonomi, dan Humaniora 3 (1), hal: 169-174.

Melisa. 2014. Analisis Pengaruh Green Product dan Green Advertising Terhadap Keterlibatan Konsumen dan Dampaknya pada Keputusan Pembelian Konsumen pada Perusahaan Lakmie Florist. Jurnal Fakultas Ekonomi Universitas Bina Nusantara Jakarta, hal: 1-12.

Mitra, Dipa. 2014. A Comparative Study on Green Marketing Effectiveness: A Data Envelopment Approach. Proceedings of the Second International Conference on Global Business, Economics, Finance and Social Sciences, Chennai, India 11-13 July 2014, pp:1-13.

Mursid, M. 2013. Manajemen Pemasaran. Jakarta: PT Raja Grafindo Persada.

Narges Delafrooz. 2014. Effect of Green Marketing on Consumer Purchase Behavior. Journal of Delafrooz et al. QScience Connect 5 (1), pp: 1-9.

Nirwana. 2013.Service Marketing Strategy. Malang: Dioma. 
Nursyamsi. 2013. Pengaruh Strategi Green Marketing pada Bauran Pemasaran Terhadap Keputusan Konsumen Dalam Membeli Rumah di Perumahan PT Asta Karya Pekanbaru. Jurnal Manajemen Fakultas Ekonomi Universitas Riau, hal: 1-13.

Nurtantiono, Andri. 2011. Analisis Sikap Pelaku Bisnis Terhadap Perbankan Syariah di Kota Surakarta. Graduasi Vol. 26, Nopember 2011, Hal. 61-74.

Putripeni, Mayang Pradma. 2014. Pengaruh Green Marketing Terhadap Citra Merek dan Keputusan Pembelian (Studi pada Konsumen The Body Shop Mall Olympic Garden Malang). Jurnal Administrasi Bisnis (JAB) 10 (1), hal: $1-10$.

Rahayu, Luh Made Pradnyani. 2017. Pengaruh Green Marketing Terhadap Keputusan Pembelian Konsumen (Survei pada Konsumen The Body Shop di Indonesia dan di Malaysia). Jurnal Administrasi Bisnis (JAB) 43 (1), hal: 121-131.

Rahul Argha. 2014. A Study of the Impact of Green Marketing Practices on Consumer Buying Behaviour in Kolkata. International Journal of Management and Commerce Innovations 2 (1), pp: 61-70.

Rakhsha, Ramin. 2011. Evaluation of Effectiveness Ofgreen Marketing Mix on Consumer Satisfasction and Loyalty: (Case Study: The East Azarbaijan Pegah Dairy Company in Tabriz, Iran). Middle-East Journal of Scientific Research 10 (6): 755-763.

Ramanakumar, K. P. V. 2012. Consumer Attitude Towards Green Products ff FMCG Sector: An Empirical Study. International Journal of Research in Commerce and Management 3 (2), pp: 34-38.

Rehman, Shakeel Ul. Usefulness of Green Marketing-Literacy and Purchase Decisions. Journal of Business and Management 16 (9), pp: 20-27.

Risyamuka, I Ketut. 2015. Pengaruh Green Marketing Terhadap Keputusan Pembelian Produk Hijau di Restoran Sari Organik Ubud. Jurnal Fakultas Ekonomi dan Bisnis Universitas Udayana (Unud), Bali, hal: 524-543.

Rizkia, Intan. 2014. Pengaruh Green Marketing Terhadap Elemen Keputusan Pembelian Produk The Body Shop di Botani Square, Bogor. Skripsi Fakultas Ekonomi dan Manajemen Institut Pertanian Bogor Bogor.

Rosdiantini, Siti Zillaiqa. 2013. Pengaruh Green Marketing Terhadap Promotion Mix dan Dampaknya pada Keputusan Pembelian PT Batara Indah (Bantex). Jurnal Fakultas Ekonomi Universitas Bina Nusantara Jakarta, hal: 1-10.

Sagala, Christina. Influence of Promotional Mix and Price on Customer Buying Decision Toward Fast Food Sector: A Survey on University Students in 
Jabodetabek (Jakarta, Bogor, Depok, Tangerang, Bekasi) Indonesia. International Journal of Scientific and Research Publications Vol.4 Issue 1, pp.1-7.

Salim, Charlina. 2015. Analisa Pengaruh Green Marketing Mix Terhadap Keputusan Pembelian Konsumen di Hotel di Surabaya Melalui Minat Beli Sebagai Variabel Perantara. Jurnal Program Manajemen Perhotelan Fakultas Ekonomi Universitas Kristen Petra Surabaya 2 (2), hal: 401-403.

Setiadi, Nugroho J. 2012. Perilaku Konsumen.Jakarta: Prenada Media.

Shabani, Nazanin. 2013. The Study of Green Consumers Characteristics and Available Green Sectors in The Market. International Research Journal of Applied and Basic Sciences 4 (7), pp: 1880-1883.

Sharma, Satish C. 2012. Green Marketing: A Gimmick or The Real Deal? International Journal of Research in Finance and Marketing 2 (2), pp: 406-414.

Sharma, Yogita. 2011. Changing Consumer Behaviour With Respect to Green Marketing A Case Study of Consumer Durables and Retailing. International Journal of Multidisciplinary Research 1 (4), pp: 152-162.

Simamora, Bilson. 2009. Riset Pemasaran. Jakarta: PT Gramedia Pustaka Utama.

Siswanto, Welly. 2015. Dampak Environmental Advertising Melalui Iklan Televisi Terhadap Minat Beli Produk Elektronik AC Inverter Panasonic pada Calon Konsumen di Surabaya. Jurnal Manajemen Pemasaran 1 (1), hal: $1-11$.

Sudhalakshmi, K. 2014. Green Marketing Mix, A Social Responsibility of Manufacturing Companies. Global Journal of Comerce and Management Perspective 3 (4), pp: 109-112.

Sugiyono. 2014.Metode Penelitian Bisnis. Bandung: Alfabeta.

Suki, Norazah Mohd. 2013. Green Awareness Effects on Consumers Purchasing Decision: Some Insights From Malaysia. International Journal APS 9 (2), pp: 49-63.

Sumarwan,Ujang. 2012.Perilaku Konsumen, Teori dan Penerapannya Dalam Pemasaran. Jakarta: Ghalia Indonesia.

Suprapti, Ni Wayan Sri. 2010. Perilaku Konsumen Pemahaman Dasar dan Aplikasinya Dalam Strategi Pemasaran. Denpasar: Udayana University Press. 
Syahbandi. 2013. Implementasi Green Marketing Melalui Pendekatan Marketing Mix, Demografi dan Pengetahuan Terhadap Pilihan Konsumen (Studi The Body Shop Pontianak). Jurnal Ekonomi, Bisnis dan Kewirausahaan 3 (1), hal: 68-86.

Tjiptono, Fandy. 2013.Strategi Pemasaran. Yogyakarta: Andi Offset.

Umar, Husein. 2013.Riset Sumber Daya Manusia Dalam Organisasi. Jakarta: PT Gramedia Pustaka Utama.

Vernekar, Sachin S.. 2011. Green Consumption An Empirical Study of Consumers Attitudes and Perception regarding Eco-Friendly FMCG Products, With Special Reference to Delhi and NCR Region. Journal of Opinion 1 (1), pp: 64-74.

Wibowo, Setyo Ferry. 2011. Karakteristik Konsumen Berwawasan Lingkungan dan Hubungannya dengan Keputusan Membeli Produk Ramah Lingkungan. Jurnal Ecosains 9 (2), hal: 192-202. 